Boise State University

ScholarWorks

Management Faculty Publications and

Presentations

Department of Management

5-1-2015

Faculty Perceptions of the Adoption and Use of Clickers in the Legal Studies in Business Classroom

Denise M. Farag

Linfield College

Susan Park

Boise State University

Gundars Kaupins

Boise State University 
This is an author-produced, peer-reviewed version of this article. The final, definitive version of this document can be found online at

Journal of Education for Business, published by Routledge. Copyright restrictions may apply. doi: 10.1080/08832323.2015.1014459

\title{
Faculty Perceptions of the Adoption and Use of Clickers in the Legal Studies in Business Classroom
}

\author{
Denise M. Farag \\ Linfield College \\ McMinnville, Oregon \\ Susan Park \\ Boise State University \\ Boise, Idaho \\ Gundars Kaupins \\ Boise State University \\ Boise, Idaho
}

\begin{abstract}
The use of clickers in the classroom can improve student engagement and motivation. However, few studies have been conducted on faculty opinions of the use of clickers. This paper measures clicker use amongst legal studies in business faculty and investigates perceptions and factors associated with adoption of clickers in the discipline. Survey results indicate that most legal studies in business faculty have either never or rarely use clickers, and very few faculty members in the discipline use clickers regularly. Instructors perceive clickers to improve teaching, but may be reluctant to adopt them because of time constraints.
\end{abstract}

Keywords: student response systems; clickers; legal studies in business; teaching with technology; higher education

\section{Introduction}

Much research has focused on the use of clickers in higher education. There is a plethora of articles regarding how clickers can be used (Barber \& Njus, 2007; Easton, 2009) or on student perceptions of clickers (Caldwell, 2007). Previous research has analyzed student perceptions of clickers in science (Duncan, 2005), physics (Reay, Bao, Li, Warnakulasooriya, \& Baugh, 2005), and K-12 (Penuel, Boscardin, Masyn, \& Crawford, 2007) courses. However, less research has been done on faculty perceptions of clicker use. Lincoln (2008) and Lewis (2013) provide two of the few empirical surveys in a business-related field that focuses on faculty perceptions regarding the adoption and use of clickers. Park and Farag (in press) and Easton (2012) found a dearth of literature concerning instructor perceptions of clickers and how clickers could be used in legal studies in business education. Using clickers in legal studies in business courses can be an effective teaching tool. They can help instructors assess student knowledge of important laws, as well as student opinions about legal topics and future policy (Park \& Farag, in press). This study assesses legal studies of business faculty perceptions regarding clickers in light of existing research on clickers. The results of this study, which provide deeper understanding of existing perceptions about the use of clickers within the discipline, may help instructors make better decisions about using this, and other, teaching technologies.

\section{Literature Review}

Students often have difficulty paying attention through an entire traditional classroom lecture. Research suggests that students can pay attention for an average of 10 to 20 minutes during a lecture before their attention declines (Sousa, 2011; Wilson \& Korn, 2007). University instructors have employed several strategies to help students stay engaged in the classroom. One increasingly popular teaching tool involves classroom response systems, or clickers. Clickers generally consist of three components: (1) a wireless handheld clicker device itself that often contains a keypad permitting students to respond to information requested by instructors; (2) the instructor's receiver that 
This is an author-produced, peer-reviewed version of this article. The final, definitive version of this document can be found online at Journal of Education for Business, published by Routledge. Copyright restrictions may apply. doi: 10.1080/08832323.2015.1014459

connects to a classroom or laptop computer; and (3) clicker software. Clicker software is used to create and pose questions. It can be integrated with presentation software such as PowerPoint, and with learning management systems such as Blackboard (Barber \& Njus, 2007; Caldwell, 2007). Students send responses to the questions via their clickers, which provide faculty with immediate input to assess their level of understanding and opinions. Instructors can summarize the data on bar charts or graphs within seconds (Lantz, 2010; Lincoln, 2009; Yourstone, Kraye, \&Albaum, 2008). Other common uses of clickers include uses include assessing prior learning, testing student engagement with assigned reading, providing feedback, breaking up lecture sessions, administering summative assessments, promoting peer learning, monitoring attendance, and fostering a sense of community (Easton, 2009).

An increasing volume of research articles discusses the various uses and benefits of clickers in the higher education classroom based on student perceptions (Good, 2013). Based on surveys of students, clicker use in the classroom offers several advantages. Clickers can make class more enjoyable (Ghosh \& Renna, 2009; Taneja, 2009), increase student engagement and motivation (Ghosh \& Renna, 2009; Bojinova \& Oigara, 2013; Eastman, Iyer, \& Eastman, 2011; Taneja, 2009), and create a positive learning environment (Kay \& LeSage, 2009; Mareno, Bremner \& Emerson, 2010). Clickers have been shown to improve college English listening and speaking skills (Yu, Chen, Kong, Sun, \& Zheng, 2014) and student attitudes toward technology (Eastman, Iyer, \& Eastman, 2011). Students report that clickers help to provide them feedback and to understand theory underlying the topic they are studying (Camacho-Minano \& del Campo, 2014).

Research also has revealed several disadvantages related to the use of clickers. For instance, some studies indicate a lack of performance differences between students who use clickers in the classroom versus those who listen to traditional lectures in the classroom, controlling for gender and home language (Tlhoaele, Hofman, Naidoo, \& Winnips, 2014; Patterson, Kilpatrick, \& Woebkenberg, 2010). One study concluded that the use of clickers does not result in higher grades (Llorens et al., 2014). Technology-based problems (e.g., clickers or software not working) and increased costs to students are also cited in the literature (Mareno et al., 2010).

Despite the possible disadvantages, “[c]licker technology presents an unrivalled opportunity to develop an engaged community of conceptually-focused, problem-solving legal learners but this can only be achieved through the engagement and commitment of managers, lecturers and ultimately the students themselves" (Easton, 2009, Conclusion section, para. 4).

While much has been written about clickers in higher education, few academic articles involve surveys of faculty perceptions of clickers in business education courses. Lincoln's (2008) study on clickers revealed the results of a survey of marketing educators based on the Unified Theory of Acceptance and Use of Technology (UTAUT), which has been the basis of numerous studies focused on identifying factors that impact technology acceptance and use. According to Venkatesh et al. (2003), UTAUT is an empirically validated model consisting of 26 variables. The model helps explain about 70 percent of the variance in an educator's acceptance and use of technology. The questions in Lincoln's UTAUT-based study cover performance expectancy (e.g., "Clickers are useful for my teaching”), effort expectancy (e.g., "Learning how to operate clicker systems is easy”), social influence (e.g., "Our students expect faculty to teach with clickers"), facilitating conditions (e.g., "I have the resources necessary to teach with clickers"), self-efficacy (e.g., "An on-campus person is readily available to assist me with clicker difficulties"), attitude toward technology (e.g., "Teaching with clickers is a good idea”), and anxiety (e.g., "I feel apprehensive about teaching with clickers"). The four moderating factors include gender, age, experience, and voluntariness of use (Venkatesh et al., 2003). The combination of the key determinants and the moderating factors have been found to significantly predict intention to use technology.

Lincoln (2008) found that "Teaching with clickers increases my classroom preparation time" was a statement that clicker users and nonusers agree on the most. However, users agreed with the statement significantly $(\mathrm{p}<.01)$ higher than non-users. "Teaching with clickers is a good idea” also had strong agreement from users and non-users but users' agreement was significantly $(\mathrm{p}<.05)$ higher than nonusers. The statement with the least agreement was "I teach with clickers because my colleagues do." Nonusers had significantly $(\mathrm{p}<.01)$ higher agreement than users. Lincoln also collected information about respondent gender, years of teaching experience, and university size among campuses throughout the U.S., but this information was not correlated with the 26 UTAUT questions. 
This is an author-produced, peer-reviewed version of this article. The final, definitive version of this document can be found online at Journal of Education for Business, published by Routledge. Copyright restrictions may apply. doi: 10.1080/08832323.2015.1014459

Lewis, Fretwell, Ryan, and Parham (2013) also used the UTAUT model to survey business faculty members at one southeastern university through an online instrument. They found that the relationship between performance expectancy and effort expectancy to use classroom technology was stronger for males. Men tend to be more taskoriented and focus on task accomplishment. The study focused on classroom technology in general rather than clickers and did not study the relationship of respondent demographic characteristics to the model's questions other than gender.

Others have studied respondent demographic characteristics in relationship to classroom technology. For example Agbatogun (2001) found a positive relationship between perceptions of e-learning and faculty years of teaching experience. Similarly, Paver, Walker, and Hung (2014) found a positive relationship between perceptions of classroom technology and faculty years of teaching experience. According to Allen and Seaman (2012), women report more communication with students through the use of technology but also experience more stress than men. Peluchette and Rust (2005) found that female faculty members were more concerned about time constraints associated with classroom technology. Xu and Meyer (2007) found that more productive faculty use technology to help them be more productive. Grasha and Yangarber- Hicks (2000) linked an instructor's feelings of competence with the decision to use technology in the classroom. Rosseau and Rogers (1998) found that older faculty members tend to use fewer new technologies. Smaller classes are associated with more faculty satisfaction and support for the use of technology (Carr, 2000). Spotts, Bowman, and Mertz (1997) found that female faculty had higher ratings than male colleagues in their perceptions of classroom technology ease of use, increased student learning, and time needed to learn how to use a technology.

\section{Research Objectives}

Given the lack of research on faculty opinions of clickers, this study addresses the following research objectives:

1. To obtain a baseline measure of the prevalence of clicker usage by legal studies in business faculty.

2. To examine the factors associated with adoption and usage of clickers by legal studies in business education instructors using variables in the UTAUT model.

3. To uncover patterns of perceptions related to the use of clickers for teaching in legal studies in business courses relative to other factors, such as gender, academic rank, and years of teaching experience.

\section{Methodology}

As Lincoln (2008) did previously, the authors concluded that the Unified Theory of Acceptance and Use Technology (UTAUT) would provide a comprehensive framework for predicting the conditions under which clicker technology adoption by legal studies in business faculty is likely to emerge. Thus, the survey instrument used to gather the data reported on in this paper is based upon UTAUT.

The UTAUT-based electronic survey developed for this study was administered through Qualtrics Survey software. The electronic survey, intended to collect data from clicker users and non-users, was sent to the membership of the Academy of Legal Studies in Business (ALSB), an organization comprised of legal studies faculty who teach undergraduate and graduate business law-related courses. The ALSB has approximately 912 members (Academy of Legal Studies in Business, 2014). Data was collected in January, 2014, from 106 ALSB legal studies faculty who responded to the survey request. Results from the survey were then tabulated and analyzed.

\section{Results}

Demographics. The sample shown in Table 1 consists mostly of males (54.8 percent), assistant, associate, and full professors (70.5 percent) with over 13 years of teaching experience (68.3 percent), but most having no teaching experience with clickers (66.0 percent). Most respondents report self-ratings of teaching better than department average (75.0 percent). A majority of survey participants teach at schools that have doctorate programs (55.8 percent) with enrollments of 15,000 or more (53.4 percent). 
This is an author-produced, peer-reviewed version of this article. The final, definitive version of this document can be found online at Journal of Education for Business, published by Routledge. Copyright restrictions may apply. doi: 10.1080/08832323.2015.1014459

As shown in Table 2, the highest degree offered at a respondent's institution correlated significantly $(\mathrm{p}<.01)$ with total enrollment at that institution. This result makes intuitive sense because larger schools would likely have more resources for higher degrees. The highest degree offered at the respondent's institution and gender were significantly $(\mathrm{p}<.01)$ correlated with the respondent's performance appraisal perceptions. Female instructors tended to lower their perceptions of their performance appraisals.

Opinions about Clickers. Table 3 shows the level of agreement clicker users and nonusers had with the 26 UTAUT statements concerning the use of clickers. Based on a scale of 1-5 $(1=$ strongly disagree, $2=$ disagree, $3=$ neither agree nor disagree, 4 = agree, 5 = strongly agree), the statement with the strongest agreement was "Clickers would be easy to use once I learned how to operate them" (3.65 rating). The second highest was "Teaching with clickers would increase my classroom preparation time" (3.59 rating). Statements with the most respondent disagreement were "Using clickers would increase my chances of getting a raise" (1.86 rating) and "I would teach with clickers because my colleagues do" (1.94 rating).

Nonusers appear to support negative opinions about clickers more strongly than users. For example, nonusers rated Statement 20 ("It would take too long to learn how to teach with clickers"), Statement 21 ("I feel apprehensive about teaching with clickers") and Statement 18 ("Teaching with clickers will take too much time") significantly higher (p $<.01)$ than users. There were a few significant $(\mathrm{p}<.05)$ differences between users and nonusers when the statements were positive about clickers. Users tended to rate statements such as Statement 5 ("Using clickers would make teaching more interesting”) significantly $(\mathrm{p}<.05)$ higher than nonusers.

Factor Analysis. The twenty-six statements concerning clickers can be narrowed to a few dimensions based on a factor analysis. Factor analysis results in Table 4 show six dimensions based on the principal components method and varimax rotation. Variables with factor loadings of .4 or higher counted for the dimensions.

Teaching quality was the dimension associated with the most statements. With eleven statements loading on this dimension, the average unweighted scores concerning agreement with the statements was 3.09. The highest loaded statements were "Teaching with clickers is a good idea" (.892) and "I would like teaching with clickers" (.875). The overall average score for statements loading at least plus or minus .4 on this factor was 3.19.

The second dimension relates to support respondents receive in using clickers. The highest loading statements were "On-campus instructors would be available to teach" (.908) and "Have on-campus support to select the best clicker to use” (.867). The average score of the statements loading onto this factor was 3.31 .

The third dimension involves respondent expectations with clickers, such as getting a raise and improving student evaluation scores. The highest loaded statement was "Clickers would be easy to use once I learned how to operate them" (.783). The average score of statements loading on this dimension was 2.18. This was the lowest score among all dimensions.

The fourth dimension was ease of use. The highest loaded statement (out of three) was "Learning how to best teach with clickers would be easy" (.899). The average score of the three statements loading on this dimension was 3.31. The fifth dimension was apprehension regarding clicker use. The highest loaded statement was "I feel apprehensive about teaching with clickers” (.913). The average score of the statements was 2.42.

The sixth dimension was preparation time to use clickers. Dimension six featured "Teaching with clickers would increase my class preparation time" with a .846 loading. The statement had a 3.59 score which makes this dimension's average (in this case, a single measure) the highest among the six dimensions.

Regression Analysis. The twenty-six UTAUT statements were organized by factors for the linear regression analyses shown in Table 5. The twenty-six UTAUT statements consisted of the dependent variables and demographic variables concerning gender, academic rank, highest business degree offered at the respondent's institution, total enrollment at the respondent's institution, years of teaching experience, respondent experience teaching with clickers, and teaching performance appraisal ratings compared to others in the department. 
This is an author-produced, peer-reviewed version of this article. The final, definitive version of this document can be found online at Journal of Education for Business, published by Routledge. Copyright restrictions may apply. doi: 10.1080/08832323.2015.1014459

Results showed that clicker experience for all but one variable within the teaching quality factor showed significant values. Those with greater clicker experience tended to support that teaching quality improved with clickers. Clicker experience also has significant positive association with a perception regarding ease of use (Factor 4) and significant negative association with apprehension toward clickers (Factor 5).

Other independent variables had much fewer associations with dependent variables. Having a higher degree was significantly associated with some of the teaching quality (Factor 1) variables. The perception that using clickers is "a good idea" and will "increase quality" had the strongest positive association. Perceptions of performance appraisal ratings were positively associated with some teaching quality variables (Factor 1). Teaching experience had some significant positive associations with perceptions of ease of use (Factor 4). Independent variables with no significant results include gender, academic rank, and highest degree offered at the respondent's institution.

\section{Discussion}

Experience with clickers appears to be the most significant of the variables associated with perceptions of the many UTAUT statements about clickers. There was a particularly high association between clicker experience and perceptions of teaching quality associated with clickers. This outcome is noteworthy - teachers who use clickers positively associate their use with teaching quality. The most differences between users and nonusers related to the amount of time expected to learn to teach with clickers, as well as apprehension and intimidation regarding learning to use them. This result may be due to nonusers' lack of experience with clickers. It may also be because they use other classroom technologies, or that other priorities, such as research and teaching, may be higher.

Teaching experience showed significant positive associations with ease of use. The result makes some intuitive sense because veteran instructors might know how to use a wide variety of teaching tools - incorporating a new teaching technique might be easier for those instructors. Further indication of experienced instructor support for ease of use is that they significantly disagreed with Statement 20 - "It would take too long to learn how to teach with clickers to make it worth my effort." Though this statement falls under Factor 1 (teaching quality), it also may be reflective of expectations that indicate they believe learning to use clickers will be easy.

The highest degree offered at the respondent's institution was positively (and in some cases significantly) associated with Factor 1 (teaching quality) variables. It would be worth investigating whether schools with doctoral degrees encourage a wide variety of technology as opposed to schools without graduate degrees.

Though having high degree programs and a large school enrollment are highly correlated, high degree programs tend to be positively related to teaching quality statements and large school enrollment tends to be negatively related. A number of possibilities for this result can be considered. Perhaps large classes in schools that have high enrollment reduce the motivation for faculty to experiment with clickers. Schools with high enrollment may also encourage established teaching techniques. More in-depth analyses of these schools would be appropriate.

\section{Limitations and Implications for Future Research}

As an initial study of the adoption and perceptions of clickers in legal studies in business education, there are some limitations that additional research would need to address. As clicker experience is significantly associated with perceptions of teaching quality, an appropriate follow- up study would be to pretest and post-test faculty perceptions of the use of clickers. In other words, did faculty change their perceptions of clickers once they used them?

Other variables can potentially influence the results, such as race, seeing (but not using) clickers used in practice, different subjects taught, resources of the respondent's institution, and adequacy and availability of training. The survey did not ask about alternatives to clickers, such as the use of polling software such as Polleverywhere.com and Top Hat, or simply counting the number of hands raised in class. A study that compared the various alternatives is a possible area of future research.

Although this study invited all active members of the ALSB to participate, a larger sample that includes all legal studies in business faculty in the U.S. would be useful to see if the same results hold. An interesting question that remains unanswered is whether legal studies in business faculty use clickers and other forms of classroom technology more, less, or the same as faculty in other business disciplines. 
This is an author-produced, peer-reviewed version of this article. The final, definitive version of this document can be found online at Journal of Education for Business, published by Routledge. Copyright restrictions may apply. doi: 10.1080/08832323.2015.1014459

It was surprising that clicker perceptions based on the UTAUT model had little or no relationship with gender given prior research that shows female instructor support for the social aspects of technology in general. Perhaps clickers might substitute for social interaction. Future research could focus more depth on the gender variable by considering motivational differences by gender in using technologies such as clickers.

\section{Conclusion}

This study surveyed legal studies in business faculty about their perceptions regarding the use of clickers. Clicker experience appears to be significantly associated with most of the UTAUT statements related to teaching quality associated with clickers. Clicker users tend to have less intimidation, apprehension, and feelings that clickers take long to learn than nonusers. Gender, academic rank, total enrollment in the respondent's institution and recent perceptions of performance appraisal ratings tended not to be associated with the UTAUT variables.

\section{References}

Abrahamson, L. (2006). A brief history of networked classrooms: Effects, cases, pedagogy, and implications. Tomei, L. A. (Ed.), Online \& Distance Learning: Concepts, Methodologies, Tools, \& Applications (pp. 78100). Hershey, PA: Information Science Reference. doi:10.4018/978-1-59904-935-9.ch009

Academy of Legal Studies in Business. (2014). 2013-14 annual report/minutes book. Oxford, OH: Author. Agbatogun, A. (2001). Faculty members' views of e-learning in Southwest Nigerian universities. International Journal of Technology, Knowledge and Society, 6(3), 2-19.

Ajzen, I. (1991). The theory of planned behavior. Organizational Behavior and Human Decision Processes, 50(2), 179-211. doi:10.1016/0749-5978(91)90020-T

Allen, I. E., \& Seaman, J. (2012). Digital faculty: Professors, teaching, and technology. Babson Survey Research Group Report. Retrieved from http://www.insidehighered.com/sites/default/server_files/DigitalFaculty.htm

Bast, C. M., \& Samuels, L. B. (2009). Legal studies scholarship: Setting the standard for excellence. Journal of Legal Studies Education, 26: 263-323. doi: 10.1111/j.1744- 1722.2009.01058.x

Bandura, A. (1986). Social foundations of thought and action: A social cognitive theory. Englewood Cliffs, NJ: Prentice-Hall.

Barber, M., \& Njus, D. (2007). Clicker evolution: seeking intelligent design. CBE-Life Sciences Education, 6(1), 18. doi:10.1187/cbe.06-12-0206

Beatty, I. (2004). Transforming student learning with classroom communication systems. Educause Research Bulletin, 3, 2-13.

Bligh, D. A. (2000). What's the use of lectures? San Francisco, CA: Jossey-Bass.

Bojinova, E., \& Oigara, J. (2011). Teaching and learning with clickers: Are clickers good for students? Interdisciplinary Journal of E-Learning and Learning Objects, 7(1), 169-184.

Caldwell, J. E. (2007). Clickers in the large classroom: Current research and best-practice tips. CBE-Life Sciences Education, 6(1), 9-20. doi:10.1187/cbe.06-12-0205

Camacho-Minano, M., \& del Compo, C. (2014). Useful interactive teaching tool for learning: clickers in higher education. Interactive Learning Environments. Advance online publication. doi:10.1080/10494820.2014.917108

Carnaghan, C., Edmonds, T. P, Lechner, T. A., \& Olds, P. R. (2011). Using student response systems in the accounting classroom: Strengths, strategies and limitations. Journal of Accounting Education, 29(4), 265283. doi:10.2308/iace.2007.22.3.391

Carnaghan, C., \& Webb, A. (2007). Investigating the effects of group response systems on student satisfaction, learning, and engagement in accounting education. Issues in Accounting Education, 22(3), 391-409. doi:10.2308/iace.2007.22.3.391

Carr, S. (2000). Many professors are optimistic on distance learning, survey finds. The Chronicle of Higher Education, 46(44), A35.

Compeau, D. R., \& Higgins, C. A. (1995). Computer self-efficacy: Development of a measure and initial test. MIS Quarterly, 19(2), 189-211.

Davis, F. D. (1989). Perceived usefulness, perceived ease of use, and user acceptance of information technology. MIS Quarterly, 13(3), 319-340.

Davis, F. D., Bagozzi, R. P., \& Warshaw, P. R. (1992). Extrinsic and intrinsic motivation to use computers in the workplace. Journal of Applied Social Psychology, 22(14), 1111-1132. doi:10.1111/j.15591816.1992.tb00945.x 
This is an author-produced, peer-reviewed version of this article. The final, definitive version of this document can be found online at Journal of Education for Business, published by Routledge. Copyright restrictions may apply. doi: 10.1080/08832323.2015.1014459

Duncan, D. (2005). Clickers in the classroom: How to enhance science teaching using classroom response systems. San Francisco, CA: Pearson-Addison Wesley.

Eastman, J. K., Iyer, R., \& Eastman, K. L. (2011). Business students’ perceptions, attitudes, and satisfaction with interactive technology: An exploratory study. Journal of Education for Business, 86(1), 36-43. doi:10.1080/08832321003774756

Easton, C. (2009). An examination of clicker technology use in legal education. Journal of Information, Law \& Technology (JILT), 3. Retrieved from http://go.warwick.ac.uk/jilt/2009_3/easton

Easton, C. (2012). Employing a classroom response system to teach law: A case study. European Journal of Law and Technology, 3(1). Retrieved from http://ejlt.org/article/view/129/193

Fies, C., \& Marshall, J. (2006). Classroom response systems: A review of the literature. Journal of Science Education and Technology, 15(1), 101-109. doi:10.1007/s10956-006-0360-1

Fishbein, M., \& Ajzen, I. (1975). Belief, attitude, intention and behavior: An introduction to theory and research. Boston, MA: Addison-Wesley.

Ghosh, S., \& Renna, F. (2009). Using electronic response systems in economics classes. Journal of Economic Education, 40(4), 354-365. doi:10.1080/00220480903297651

Good, K. C. (2013). Audience Response Systems in higher education courses: A critical review of the literature. International Journal of Instructional Technology and Distance Learning, 10(5), 19-34.

Grasha, A. F., \& Yangarber-Hicks, N. (2000). Integrating teaching styles with instructional technology. College Teaching, 48(1), 2-10. doi:10.1080/87567550009596080

Guernsey, J. B. (1977). H. Richard Crane: Oersted medalist for 1976. American Journal of Physics, 45(6), 507. doi:10.1119/1.10947

Hoekstra, A., \& Mollborn, S. (2013). How clicker use facilitates existing pedagogical practices in higher education: Data from interdisciplinary research on student response systems.

Learning, Media and Technology, 37(3), 303-320. doi:10.1080/17439884.2011.568493 Houle, P.A., Reed, D., Vaughan, A.G., \& Clayton, S.R. (2013). Using laptop computers in class: A student motivation perspective. Journal of Learning in Higher Education, 9(2), 83-92.

Jones, S., Henderson, D. \& Sealover, P. (2009). "Clickers” in the classroom. Teaching and Learning in Nursing. 4(1), 2-5. doi:10.1016/j.teln.2008.06.001

Jossem, E. L. (2007). Remembering Dick Crane. The Physics Teacher, 45(6), 330-331. doi:10.1119/1.2768684

Judson, E. (2002). Learning from past and present: Electronic response systems in college lecture halls. Journal of Computers in Mathematics and Science Teaching, 21(2), 167-181.

Kay, R. H., \& LeSage, A. (2009). Examining the benefits and challenges of using audience response systems: A review of the literature. Computers \& Education, 53(3), 819-827. doi:10.1016/j.compedu.2009.05.001

Keogh, P., \& Wang, Z. (2010). Clickers in instruction: One campus, multiple perspectives. Library Hi Tech, 28(1), 821.

Lantz, M. E. (2010). The use of "clickers" in the classroom: Teaching innovation or merely an amusing novelty? Computers in Human Behavior, 26, 556-561. doi:10.1016/j.chb.2010.02.014

Lewis, C. C., Fretwell, C. E., Ryan, J., \& Parham, J. B. (2013). Faculty use of established and emerging technologies in higher education: A unified theory of acceptance and use of technology perspective. International Journal of Higher Education, 2(2), 22-34. doi: 10.5430/ijhe.v2n2p22

Lincoln, D. J. (2008). Teaching with clickers in the large-size principles of marketing class. Marketing Education Review, 18(1), 39-45.

Lincoln, D. J. (2009). Student response systems adoption and use in marketing education: A status report. Marketing Education Review, 19(3), 25-40.

Llorens, S., Arribas, E., Arroyo-Jiminez, M. M., Artacho, E., Carmona, M., Domingo, B., Fernandez, M., ... Najera, A. (2014). Evaluation of the possible impact of clickers on the grade obtained by students in the radiology subject, at the faculty of medicine in Albacete. In L. G. Chova, A. L. Martinez, \& I. C. Torres (Eds.), INTED2014 Proceedings: $8^{\text {th }}$ International Technology, Education, and Development Conference (pp. 2707-2714). Valencia, Spain: IATED Academy.

Marchewka, J. T., Liu, C., \& Kostiwa, K. (2007). An application of the UTAUT model for understanding student perceptions using course management software. Communications of the IIMA, 7(2), 93-104.

Mareno, N., Bremner, M., \& Emerson, C. (2010). The use of audience response systems in nursing education: Best practice guidelines. International Journal of Nursing Education Scholarship, 7(1). doi:10.2202/1548923X.2049 
This is an author-produced, peer-reviewed version of this article. The final, definitive version of this document can be found online at Journal of Education for Business, published by Routledge. Copyright restrictions may apply. doi: 10.1080/08832323.2015.1014459

Oye, N. D., Iahad, N. A., \& Ab Rahim, N. Z. (2012). Acceptance and usage of ICT by university academicians using UTAUT model: A case study of university of Port Harcourt, Nigeria. Journal of Emerging Trends in Computing and Information Sciences, 3(1) 81-89. 10.4018/978-1-4666-1957-9.ch013

Park, S., \& Farag, D. (in press). Transforming the Legal Studies Classroom: Clickers and Engagement. Journal of Legal Studies Education.

Patterson, B., Kilpatrick, J. \& Woebkenberg, E. (2010). Evidence for teaching practice: the impact of clickers in a large classroom environment. Nurse Education Today, 30, 603-607. doi:10.1016/j.nedt.2009.12.008

Paver, J., Walker, D., \& Hung, W. (2014). Adjunct faculty characteristics that may predict intention to integrate technology into instruction. Community College Journal of Research and Practice, 38, 859-872. doi:10.1080/10668926.2013.819790

Peluchette, J., \& Rust, K. A. (2005). Technology use in the classroom: Preferences of management faculty members. Journal of Education for Business, 80, 200-205. doi:10.3200/JOEB.80.4.200-205

Penuel, W. R., Boscardin, C. K., Masyn, K., \& Crawford, V. M. (2007). Teaching with student response systems in elementary and secondary education settings: A survey study. Educational Technology Research and Development, 55(4), 315-346. doi:10.1007/s11423- 006-9023-4

Reay, N. W., Bao, L., Li, P., Warnakulasooriya, R., \& Baugh, G. (2005). Toward the effective use of voting machines in physics lectures. American Journal of Physics, 73, 554-558. doi:10.1119/1.1862638

Rosseau, G. \& Rogers, W. (1998). Computer usage patterns of university faculty members across the lifespan. Computers in Human Behavior, 14, 417-428. doi:10.1016/S0747- 5632(98)00014-4

Simpson, V., \& Oliver, M. (2007). Electronic voting systems for lectures then and now: A comparison of research and practice. Australasian Journal of Educational Technology, 23(2), 187.

Sousa, D. A. (2011). How the Brain Learns (4th ed.). Thousand Oaks, CA: Sage.

Spotts, T. H., Bowman, M. A., \& Mertz, C. (1997). Gender and use of instructional technologies: A study of university faculty. Higher Education, 34, 421-436. doi:10.1023/A:1003035425837

Tan, P. J. B. (2013). Applying the UTAUT to understand factors affecting the use of English e- learning websites in Taiwan. SAGE Open, 3(4), 1-12. doi:10.1177/2158244013503837

Taneja, A. (2009). The influence of personal response systems on students' perceived learning outcomes and course satisfaction. Journal of Circuits, Systems and Computers, 25(2), 5-11.

Taylor, S., \& Todd, P. A. (1995). Understanding information technology usage: A test of competing models. Information Systems Research, 6(2), 144-176. doi:10.1287/isre.6.2.144

Thompson, R. L., Higgins, C. A., \& Howell, J. M. (1991). Personal computing: Toward a conceptual model of utilization. MIS Quarterly, 15(1), 125-143.

Thoaele, M., Hofman, A., Naidoo, A. \& Winnips, K. (2014). Using clickers to facilitate interactive engagement activities in a lecture room for improved performance by students. Innovations in Education and Teaching International, 51, 497-509. doi:10.1080/14703297.2013.796725

Venkatesh, V., \& Davis, F. D. (2000). A theoretical extension of the technology acceptance model: Four longitudinal field studies. Management Science, 46(2), 186-204. doi:10.1287/mnsc.46.2.186.11926

Venkatesh, V., Morris, M. G., Davis, G. B., \& Davis, F. D. (2003). User acceptance of information technology: Toward a unified view. MIS Quarterly, 27(3), 425-478.

Wilson, K., \& Korn, J. H. (2007). Attention during lectures: Beyond ten minutes. Teaching of Psychology, 34(2), 85-89. doi:10.1080/00986280701291291

Xu, Y. \& Meyer, K. A. (2007). Factors explaining faculty technology use and productivity. The Internet and Higher Education, 10, 41-52. doi:10.1016/j.iheduc.2006.10.004

Yourstone, S. A., Kraye, H. S., \& Albaum, G. (2008). Classroom questioning with immediate electronic response: Do clickers improve learning? Decision Sciences Journal of Innovative Education, 6, 75-88. doi:10.1111/j.1540-4609.2007.00166.x

Yu, Z., Chen, W., Kong, Y., Sun, X. L., \& Zheng, J. (2014). The impact of clickers instruction on cognitive loads and listening and speaking skills in college English class. PLoS ONE, 9: e106626. doi:10.1371/journal.pone.0106626 